\title{
Indigenous peoples and salmon stewardship: a critical relationship
}

$\frac{\text { Courtney Carothers }}{5}^{1}, \underline{\text { Jessica Black }}^{1}$, $\underline{\text { Stephen J. Langdon }}^{2}$, Rachel Donkersloot $^{3}$, Danielle Ringer ${ }^{1}, \underline{\text { Jesse Coleman }}^{4}, \underline{\text { Erika R. Gavenus }}^{l}$ ${ }^{5}$, Wilson Justin $^{6,7}$, Mike Williams $^{8,9}$, Freddie Christiansen $^{10}{ }^{10}$ Jonathan Samuelson $^{9,11}$, Carrie Stevens ${ }^{1}$, Brooke Woods ${ }^{1,12}$, S. Jeanette

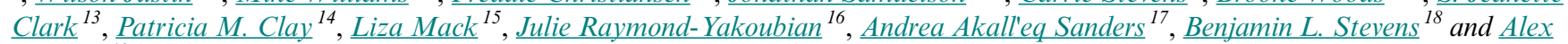
Whiting

ABSTRACT. Indigenous Peoples and salmon in the lands now called Alaska have been closely entwined for at least 12,000 years. Salmon continue to be central to the ways of life of Alaska Natives, contributing to physical, social, economic, cultural, spiritual, psychological, and emotional well-being. Salmon have also become important to Alaskan settlers. Our research and advisory team conducted a synthesis of what is known about these diverse human-salmon relationships, drawing on 865 published scientific studies; Indigenous knowledge; state, federal, and tribal data; archival materials; oral histories; and cross-cultural dialogs at working group meetings. Two important socio-cultural dimensions of salmon-people systems emerged from this synthesis as fundamentally important but largely invisible outside of Indigenous communities and the social science disciplines that work closely with these communities: (1) the deep relationships between Indigenous Peoples and salmon and (2) the pronounced inequities that threaten these relationships and stewardship systems. These deep relationships are evident in the spiritual, cultural, social, and economic centrality of salmon across time and cultures in Alaska. We describe Indigenous salmon stewardship systems for the Tlingit, Ahtna, and Central Yup'ik. The inequities in Alaska's salmon systems are evident in the criminalization and limitation of traditional fishing ways of life and the dramatic alienation of Indigenous fishing rights. The loss of fish camps and legal battles over traditional hunting and fishing rights through time has caused deep hardship and stress. Statewide, the commodification and marketization of commercial fishing rights has dispossessed Indigenous communities from their human and cultural rights to fishing ways of life; as a result, many rural and Indigenous youth struggle to gain access to fishing livelihoods, leaving many fishing communities in a precarious state. These deep relationships and relatively recent fractures have motivated a concerted effort by a group of committed Indigenous and western scholars to better understand the root causes and opportunities for redress, as well as to document the breadth of research that has already been conducted, in an effort to improve the visibility of these often-overlooked dimensions of our salmon systems.

Key Words: Alaska; Alaska Native; Indigenous Peoples; salmon; stewardship

\section{POSITIONALITY STATEMENT}

Inspired by our team members and recent papers (e.g., Reid et al. 2020), we begin this paper with a positionality statement. The intellectual guidance of Ahtna Elder Wilson Justin and Yup'ik Elder Mike Williams, and the Unangâx/Aleut, Koyukon, SugpiaqlAlutiiq, Yup'ik, and Dena scholars, leaders, fishermen, students, and activists who shared knowledge, experiences, and reflections were the central foundation of this work. Our team of authors was brought together through a larger project exploring salmon and people in Alaska (State of Alaska Salmon and People (SASAP) 2019). Jessica Black (Gwich'in scholar) and Courtney Carothers (settler scholar) led a social and cultural team of this effort (alongside Rachel Donkersloot who led a group focused on well-being and Stephen Langdon who led a governance and subsistence team). We struggled with how to collectively present some of our work in this academic publication, including grappling with the appropriate way to acknowledge the contributions of Indigenous Elders and scholars within academic norms of authorship. When discussing some of our concerns, Wilson Justin offered "In honor and homage to first, our ancestors, then the next generation and to friendship and purpose I add my name to these fellow travelers..." So, it is in this way that we add our names following academic conventions, but seek to advance a holistic approach to authorship that weaves in voices from different cultures and multiple generations. We say Tsin'an, Chin'an, Quyana, Quyanaasinaq, Qagaasakung, Mahsi' choo, Ena baasee, Thank you to this team of scholars and leaders committed to equity and change for more just and sustainable futures for all beings, including salmon and our readers who may help us shift the norms and processes of how we create, represent, publish, share, and attribute such work.

\section{INTRODUCTION}

The first time I remember hearing about [the Alaska Department of] Fish and Game, I was still very little. My family and I were getting humpies (qaanayux I Oncorhynchus gorbuscha) at Ram Creek in King Cove to make yukulax (dried salmon). All of a sudden, my Ba -Alex Kenezuroff-told us to get out of the creek and hide in the grass. He had heard a plane and did not want us to get caught "robbing the creek." This is one of the first times that I can remember realizing that we had rules to follow about how we got our fish that would sustain us for the winter. We were not by any means "robbing the creek," but simply getting our fish for winter as we always had done from that creek from time immemorial.

${ }^{1}$ University of Alaska Fairbanks, ${ }^{2}$ University of Alaska Anchorage, ${ }^{3}$ Coastal Cultures Research, ${ }^{4}$ Wildlife Conservation Society Arctic Beringia Program, ${ }^{5}$ University of British Columbia, ${ }^{6} \mathrm{Mt}$. Sanford Tribal Consortium, ${ }^{7}$ Chistochina Enterprises, ${ }^{8}$ Akiak Native Community, ${ }^{9}$ Kuskokwim River Inter-Tribal Fish Commission, ${ }^{10}$ Old Harbor Native Corporation, ${ }^{11}$ Native Village of Georgetown, ${ }^{12}$ Yukon River Inter-Tribal Fish Commission, ${ }^{13}$ National Center for Ecological Analysis and Synthesis, University of California Santa Barbara, ${ }^{14}$ NOAA Fisheries, ${ }^{15}$ Aleut International Association, ${ }^{16}$ Kawerak, Inc., ${ }^{17}$ With Real People, Native Peoples Action, ${ }^{18}$ Tanana Chiefs Conference, ${ }^{19}$ Native Village of Kotzebue 
Recalling the situation, it makes me aware of how young we are as Native people when we are made aware that the resources, which define the cornerstone of our culture, are managed by outside entities. Liza Mack in Mack (2019)

Alaska's salmon ecosystems are the foundation for deep cultural values and social relationships across the state. Salmon have been a cultural keystone species for many of the Indigenous cultures for millennia. In some regions, salmon and people have been closely entwined for at least 12,000 years. By comparison, EuroAmerican colonization occurred only in the last $2 \%$ of the deep time period that people and salmon have been forming close relationships in these lands and waters. This relatively short period of time has brought about radical changes impacting traditional ways of life for Alaska Natives and salmon-people relationships. These changes include the atrocities of invasion and colonization: genocide, epidemic diseases, slavery, child abduction and forced boarding schools, language suppression, cultural assimilation, and industrial-scale resource extraction; along with changes in resource access and management due to Eurocentric federal and state governance shifts, land claims, tensions between fisheries users, and privatization of access. These waves of change continue to transform relationships between people and salmon and fishing practices today.

Salmon continue to be central to the ways of life of Indigenous Peoples, contributing to the physical, social, economic, cultural, spiritual, psychological, and emotional well-being of people and communities. They also form the backbone of a robust commercial fishing economy, are highly valued as a wild food source, and support a healthy resident and tourist recreation industry. Overall, salmon play integral and diverse roles in the society, cultures, and economies of Alaska. As part of the State of Alaska Salmon and People (SASAP) knowledge synthesis project, we explored the social and cultural dimensions of salmon systems in Alaska (SASAP 2019). We found a major goal of the project was to increase the visibility of important socio-cultural dimensions of salmon systems that are often overlooked in western fisheries science and management. Our work challenges the assumption that this kind of data does not exist; for this project, we located hundreds of sources of data to speak to these relationships. As the quote above alludes, exploring these connections over time also reveals deep fractures and disconnections resulting from settler colonialism.

\section{METHODS}

The State of Alaska Salmon and People project attempted to gather and synthesize the state of knowledge about salmon systems in Alaska (SASAP 2019). The first phase of this effort focused on working groups that synthesized data and knowledge in four primary domains: biophysical, socio-cultural, economic, and governance. A second phase of the project brought together working groups to synthesize data for specific case studies, including one on salmon and human well-being (Donkersloot et al. 2020). The first phase socio-cultural group had close membership overlap with the governance and well-being working groups. We met several times in person (2- to 5-day meetings) in Anchorage, Alaska, and Santa Barbara, California, over the course of a few years. These discussions were central to identifying key themes of interest to explore in the published literature and other data sources as described below.
In consultation with our regional advisors, we gathered 865 published sources of data on people-salmon relationships (see SASAP 2019). We conducted inductive thematic coding of 10 to 15 key sources per region (see Fig. 1). To identify these key sources, we took a purposive sample of high priority sources to review, annotate, and summarize for each region. These high priority sources were identified by our socio-cultural research team and advisors to be most pertinent to the social and cultural dimensions of human-salmon relationships, and a suite was chosen for each region to reflect diversity of people-salmon relationships (e.g., commercial, recreational, subsistence). These references were thematically coded in Atlas.ti. This coding process helped us to draft regional summaries of the social and cultural dimensions of salmon fisheries (available at SASAP 2019).

Fig. 1. Map of the regions used for the State of Alaska Salmon and People project.

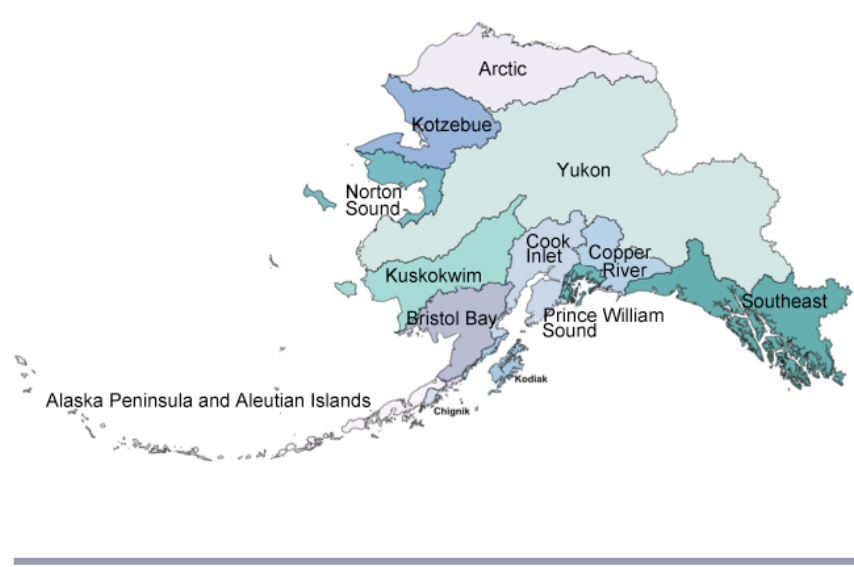

Recognizing that social and cultural dimensions are not always well documented in written form or available data sources, we also generated a list of repositories of archival data, oral histories, and other sources of Indigenous knowledge (available at SASAP 2019). We synthesized knowledge from our qualitative data analyses, regional summaries, the repositories of complementary data, and expert input from our working group discussions to identify and describe socio-cultural dimensions of salmonpeople systems in regions across Alaska. From this synthesis, we identified priority findings described below. We continued dialog among our group members as we developed this paper. As a group of Indigenous and settler authors, we refer to Indigenous Peoples using pronouns "they/we" and "their/our" to reflect this joint authorship.

\section{RESULTS AND DISCUSSION}

Our thematic coding of a subset of documents for each region identified roughly 20 key themes of interest to understanding the social and cultural dimensions of salmon systems (see Appendix 1 for more detail). These key themes included: the centrality and importance of salmon in the mixed economies of many rural regions of the state: food and livelihood security and sovereignty, subsistence and sharing, and diverse social, economic, and cultural relationships. A number of concerns were expressed throughout the regions, including: industrial development, governance and user-group conflicts, privatization of access, and 
shifts in abundance and price. Continued dialog on these themes over the course of several years of the State of Alaska Salmon and People project revealed that two core themes are of central importance; but, they are not well-known or acknowledged outside of Indigenous communities and the social science disciplines that work closely with these communities. These two themes are: (1) the deep relationships and long-term stewardship between Indigenous Peoples and salmon and (2) the pronounced inequities of contemporary salmon-people systems.

Salmon and Indigenous Peoples have been inextricably linked across the lands now called Alaska since time immemorial. Indigenous cultures have origin stories that center on salmon and salmon people. Ancient stories provide teaching through salmon and salmon-people relationships. Current practices draw on deep knowledge to teach younger generations proper ways of being. In our review, we also uncovered inequities and socio-cultural disconnects in these long-term relationships in Alaska's salmon systems; these are particularly evident in the criminalization and regulation of traditional fishing ways of life and the dramatic loss of Indigenous commercial fishing rights. The loss, through time, of fish camps and legal battles over traditional hunting and fishing rights have caused profound and ongoing hardship and stress between traditional practices and resource management systems. Statewide, commercial fishing rights have shifted toward urban, nonAlaskan, nonIndigenous residents, and as a result, many rural and Indigenous youth struggle to gain access to fishing livelihoods, leaving some traditional fishing communities in a precarious sustainability crisis. The following sections further expand on these themes based on the synthesis of the document analyses, data repositories, and working group conversations.

\section{Deep Relations between Indigenous Peoples and Salmon}

Alaska Natives have a deep relationship with Salmon, dating back 10,000 plus years. Stories from our parents, Elders, and Ancestors resound with stories of Salmonpeople relationships and reciprocities; from songs sung to greet the arrival of Salmon on the Yukon River to strict rules regarding appropriate behavior to ensure the Salmon would return on the Copper River. Each year the Salmon returned. This timeless relationship wove itself into deep connections predicated on spirituality, respect, and reciprocity. Indeed this relationship did and continues to exist between humans and the land, animals, water, and other nonhuman relatives as well. Justin and Black (2019).

The earliest peoples to live in the lands that are now called Alaska lived in relationship with salmon. In the Interior region of Alaska, these relationships have been documented in the archaeological record back to 11,500 years ago in the Upward River Sun site on the Tanana River (Halffman et al. 2015, Potter et al. 2017). Indeed, across Alaska, where people and salmon occur together, cultures developed in relation to salmon. Indigenous knowledge and stewardship values and practices have sustained salmon and people in Alaska for millennia. Across the worldviews and practices of the Indigenous Peoples were/are shared principles. As Langdon (2019) states:

First, all entities have spiritual essences (personhood) that are fundamentally similar to those of humans and that those spiritual essences are attentive, sentient, volitional and require respectful treatment. Second, human beings have moral and existential obligations to maintain respectful relations with living and other beings on whom they depend in order for those forms to continue to give themselves to humans for the survival and wellness of both. Third, the spirits of living forms, including humans, upon death pass into another dimension and from there return to the living world through rebirth. This process is referred to as "cosmological cycling" and is dependent on human actions, ritual and otherwise, for the continuity of existence (Fienup-Riordan 1983:189). Human beliefs and behaviors have been codified and passed on through mythic charters/covenants, spiritually informed ritual practices and liturgical forms handed down from generation to generation. While spiritually informed and motivated, Indigenous Alaskans closely observed salmon comings and goings, built complex understandings of salmon behavior, requirements, habitats and life cycles and mobilized the accumulated empirical knowledge to utilize and sustain salmon populations. They also created social systems and rules to regulate access, distribution, and ensure non-wasteful use of salmon.

Here, we present accounts of the Tlingit, Ahtna, and Central Yup'ik, demonstrating the governance of relationships between Alaska's first people and salmon. These cultural groups were explored in the governance working group of the State of Alaska People and Salmon project (Langdon 2019); Elders from these cultural groups were closely engaged in our larger project and previous research (e.g., Langdon 2006 a, b). Importantly, coauthor Elder Wilson Justin cautions us to understand these depictions as incomplete and the importance of historical context. The Ahtna and all Indigenous Peoples in Alaska share a history of violent and assimilative colonialism. "You can't be Athabascan in 2020 without recognizing the last 150 years. What happened in those dark times is part of being here now." He summarized some of his thoughts, explaining the difficulty of reviewing and approving depictions of Ahtna Peoples and systems.

The Ahtna that was in place during the 50 to 100 years of epidemics had gone through fundamental changes from its original form. Boundaries shifted dramatically, and the population shrunk to a fraction. The Ahtna at the time of contact with U.S. was still in the process of recovery and was faced with the issue of rebuilding a fallen population. Regaining its former status meant establishing governance, boundaries, and language. All were badly impacted and in some cases nearing extinction. Again, the only sources of this parallel universe of the Ahtna were in Stories and Potlatches, which were in the original high language and were contested on an immediate basis upon contact by first military, then traders, then missionaries.

The rewriting of history in verbal legend was extensive. For instance during the Medicine Man Wars, which was an earth-shattering event in Ahtna history, Batzulnetas was a training place for fighting Ahtna men, but no trace of that history is found today.

Research, although limited, gives us anchor in terms of time but is silent on events. Example again: the Medicine Man wars, which culminated in Ahtna having to bring in 
mercenaries for the last battles, are said to have lasted 30 years in eastern Ahtna, but is relatively unheard in central Ahtna, but is spoken in western Ahtna as a distant event. The two sisters story is another example. Three sisters in Chitna/Nabesna. Two sisters in other Clans and in general tied to the end of Ahtna presence in Cook Inlet or a major event in Lower Salcha.

In other words, agreeing to having been here a great length of time is easy. Antiquity is common to our Traditions. What happened from 1750 to 1950 is a whole different universe. That was what intrigued me since what was whispered in my youth had very little bearing on most of the common story telling. In essence, what was left out was governance and structure. Or as the military would say, flag planting. Wilson Justin, Chistochina, August 2020

Taking this into consideration, we present these accounts (Text Boxes 1-3) as a western representation of a limited gathering of oral histories and archaeological study of the deep time we reference. We share these not as a definite history of diverse Alaska Native groups, but rather to help document and make visible the depth of salmon governance developed over millennia. Between antiquity and today, many assaults have been waged against Indigenous Peoples and Tribal sovereignty to live selfdetermined lives and govern in Indigenous ways. It is this decisionmaking power and process - how groups of people come together in what ways, for what reasons, in what places, and at what times - that Wilson Justin directs us to consider in our dialogs. As an Elder and intellectual guide in our process, he puts emphasis on a key goal moving forward: to recapture the Indigenous ability to make decisions according to Indigenous governance systems, not those of settler colonial states. Indigenous governance systems are largely invisible in the western institutions of fisheries science, education, and management in Alaska today, and as a result, are almost completely unknown to nonIndigenous peoples and most decision makers setting policy for people-fish relations. This lack of awareness and respect for Indigenous stewardship (and sovereignty) and cultural pluralism with regard to salmon cause deep conflict, stress, and hardship — as we discuss in the following section.

Across Indigenous cultures of Alaska, there is a foundational importance of spirituality, respectful and reciprocal relationships between people and other beings, and active management of ecosystems (Fig. 2). We see similarity across Indigenous cultures of Alaska who view salmon as nonhuman kin who return to give themselves to people. If not harvested, or if not treated well once harvested, they may be offended and not return. We see governance systems based on respect, reciprocity, and distributional equity. We see Indigenous stewardship systems that actively manage salmon, other beings, habitats, and larger ecosystems. These systems employ territorial control, innovative and sustainable harvesting, sex-selective harvesting, habitat management, predator control, stock enhancement, temporal management, among many other dimensions. The importance of proper spiritual, human, and animal relations was and continues to be a common thread across all Indigenous cultures of Alaska, along with the stewardship practices that sustain lands and waters across the diverse ecosystems of the state.
Fig. 2. Shannon Hardy and Jessica Black cutting Łuk Choo on the Yukon River, 2017. Photo credit: Michael Hardy.

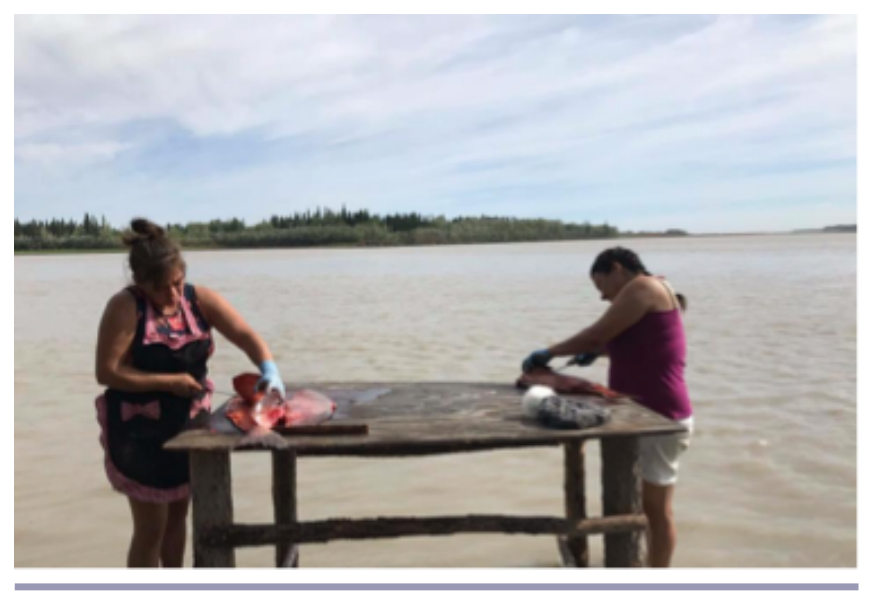

Ideas about stewardship and social relations with salmon changed radically with Russian and Euro-American invasion and colonization beginning in the 18th century. As Langdon (2019) describes:

These settlers brought with them a worldview grounded in the Biblical account of existence with humans as the chosen life form "made in the image of God" endowed by the creator with a spirit (soul) that would pass on to another existence and not return to this world. Further, other living forms did not have spirits like human souls and were to be used by human beings for their purposes. No relationship of a spiritual nature is posited in the Biblical worldview between humans and other living entities. The Biblical worldview is linear-life begins at birth, proceeds on a trajectory of existence, and ends with death. There is no spirit of the life form that will return to earthly existence through rebirth. The presence of fish and animal populations does not depend on human relations with those organisms in the Biblical worldview.

The concepts used today in U.S. and Alaska fisheries management, like tragedy of the commons and maximum sustained yield, are based on these Eurocentric worldviews and the separation and domination of humans over other species. These concepts are offensive to many Indigenous worldviews, as Ahtna Elder and coauthor Wilson Justin explains:

We're all familiar with how, in English, things get broken into specific aspects of activities and defined by activities. You go to play a hockey game and you know what it's all about. Hockey game has rules. You don't play hockey in a basketball game. Doesn't work like that in Athabascan. It's all one game. It's all one resource. It's all one creation, and it's all one set of responsibility. So you have to learn not only how to accommodate salmon and river streams, you have to consider yourself a part of the salmon world. Not the other way where the salmon is a part of your entitlement for catch. You're intruding into salmon realm, and when you intrude into salmon realm, you have to give fair and just accounting of yourself. You do that with 
ceremony of prayers and songs. And then it goes another step further. You go caribou hunting. Well, there is no difference between hunting caribou and catching salmon. You still have to account to the caribou; you're still intruding in their world. Okay you go one step further, let's do sheep. Well there's no difference between sheep, caribou, and salmon. You're still assigned the responsibility of accounting for your intrusion into that world. Now that's extraordinarily easy to speak to in Athabascan, and I've found it extraordinarily, virtually impossible to speak to in English, in the western world.

Just think of this term "sustained yield." \{laughing\} In Indian, that would translate to, say into salmon, "You owe me your life, so get up here right now and die." That's the way it would translate in Athabascan from English, the sustained yield concept. That's why you never hear me say sustained yield-you just can't do that. The salmon, you're intruding in the salmon's world. So, it would be so offensive in our way that if you spoke like that they would run you out of camp until you go back to where you come from. That would be enough for the traditional marriages to be broken up and separated, which is almost impossible to do. So that's the level of offense you're looking at when you use these doggone terms like sustained yield. Wilson Justin, interview, Anchorage, Alaska, USA, September 2019

Radical changes since Russian and Euro-American colonization have impacted traditional ways of life and salmon-people relationships, ranging from violence and assimilation (e.g., disease, slavery, boarding schools, resource extraction) to changes in resource access and management (e.g., federal and state governance shifts, land claims, tensions between fisheries users, privatization of access). Although these waves of change continue to transform relationships between people and salmon and fishing practices today, Indigenous Peoples across Alaska maintain their/ our knowledge and stewardship systems and their/our cultures, many focused around salmon. However, our review also revealed distinct and deep inequities in salmon-people systems that threaten these traditional salmon ways of life.

\section{The Tlingit-Salmon Relationship (Author: Steve Langdon)}

The Tlingit are the Indigenous occupants of the northwestern shores and islands of North America from the Bering River to Dixon Entrance. Archeological and linguistic evidence indicates that Tlingit ancestors were present from at least 6000 years ago (Langdon 2014). Tlingit society was/is organized into approximately 15 socio-geographic units, referred to as kwaans. Kwaans in turn were/are composed of core clans who owned lands and resource territories within the kwaan and cooccupied winter villages in the kwaans, residing in substantial wood plank houses. Clans were/are organized into two divisions (moieties) - Raven and Eagle/Wolf - and social rules banned intermarriage within a clan or moiety so that persons were required to marry a person of another clan and in the opposite moiety. This social and moral rule set in motion a series of exchanges between the clans that can be referred to as "obligatory reciprocity."

Tlingit society had/has exceptionally strong property concepts. Clans were corporate units in that they owned both tangible and intangible property. Clan leaders (sha da hunee) were/are trustees who coordinate social relations, and were/are responsible for maintaining the corporate trust and passing it on to descendants. Special relations with places were/are memorialized in at.oowobjects, stories, dances, crests - that represent the clan history and claims to the location, territory, or resource. Salmon stream ownership was one of the most important forms of property held by clans. Salmon streams were under the control of stream chiefs (heen saati) who exercised governance by determining who had access, harvest timing, technology, and location of harvests. In general, other Tlingit respected clan claims to streams, but if they were violated, Tlingit would use violence to protect their claims.

Salmon were/are the most important resource for the Tlingit. Tlingit relations with salmon combined spiritual understandings and perceptions with pragmatic empirical engagement, knowledge acquisition, and practical intervention. The spiritual underpinnings of the Tlingit relation with salmon are conveyed in the mythic charter/covenant now referred to as the Salmon Boy story. According to the account, a young boy was taken by the Salmon People to their village underwater following his insult to a piece of dried salmon he was offered as food. The boy saw that under their skins, salmon were people and was taught many things by the Salmon leader about how humans must treat salmon with respect in various ways so that salmon could travel back from the ocean to their spawning streams. After several years, he returned with the Salmon people and was captured by his father. After his transformation back to human form, he told his family and relatives what he learned from the Salmon people about how they were to be treated so that they could return and be reborn. These teachings were passed down through the generations and, as a charter/covenant, provide the prisms through which Tlingit experience and relate to salmon and the prescriptions for how salmon are to be treated with respect.

Respect for salmon was/is shown by Tlingit in numerous ways, including crying out a greeting to them as they jump out of the water when approaching a stream, singing and dancing for them as they enter the streams, carefully handling them as they are harvested and processed, and releasing their spirit so it can return to their underwater home and be reborn (Langdon 2006b). In the realm of human social activities, salmon were/are honored as clan crest symbols, by creating beautiful images of them on blankets, hats, boxes, screens, and totem poles and by giving humans names based on salmon characteristics. They were/are to be spoken of and to with respect and never insulted or abused.

Archeological evidence shows that Tlingit began building intertidal fishing structures to capture salmon over 5000 years ago (Smith 2011). This evidence is most abundant in southern southeast Alaska where remains of intertidal fishing structures are found at the mouths of many streams, peaking in abundance around 2000 years ago (Smith 2011). Approximately 1000 years ago, the Tlingit developed an intertidal salmon fishing technology of semicircular tidal traps that allowed salmon to ascend to their spawning grounds on each high tide and only captured those that backed out on the ebb tide (Langdon 2006a). This innovation is termed "tidal pulse fishing" (Langdon 2006a).

A number of governance practices were developed by the Tlingit to sustain salmon. Informed by the Salmon Boy account, Tlingit developed the concept of ish, a deep hole in a stream where salmon congregate to rest as they proceed up a stream to their spawning 
grounds. The ish was used as an index of return adequacy - the heen sati required that it be filled with salmon before harvests would be allowed below the ish in the intertidal area or in the stream (Langdon 2006b). Tlingit were/are enjoined to take only what they needed, to not waste any portion of the salmon, and to store them safely so they do not spoil (Langdon 2006b).

The Tlingit harvested/harvest selectively by sex. Historically, they took mostly males, in a ratio of 3 to 1 (Langdon 2006b). The heen sati monitored the stream and removed fallen rock, excess brush, or tree debris that blocked the upstream movement of salmon. When beaver dams blocked sockeye salmon access to their spawning locations, the heen sati had the dams taken out (Langdon 2006b). Tlingit viewed Dolly Varden trout (Salvelinus malma) and certain birds as endangering salmon egg deposition and outmigration and limited their numbers to control excessive depredations on young salmon. In streams where salmon runs had decreased or had been blocked for some time by slides, Tlingit transplanted salmon in various ways to replenish the streams (Langdon 2006b). This was done by bringing male and female salmon from other stream systems and releasing them at the stream mouth or, in the case of sockeye salmon, at the lake outlet (Langdon 2006b). In at least one case, this procedure was used in an attempt to establish a late chum run in a system in order for the clan to have access to salmon later in the year when they had time to process them (Thornton et al. 2015). The governance system of salmon engagement developed by the Tlingit was successful in sustaining highly productive systems for thousands of years. The system can be characterized by the term "relational sustainability" - through spiritually inspired prescriptions and actions, Tlingit maintained existence, as they knew it.

The Ahtna-Salmon Relationship (Written and reviewed by Steve Langdon and Wilson Justin (Ahtna))

The Ahtna live in the Copper River valley above Miles Lake to its headwaters and in the upper Susitna valley to the west. The Copper River has numerous tributaries that support runs of king, sockeye, and silver salmon, including the Chitina, Tonsina, Tazlina, Klutina, Gulkana, Slana, Mentasta, and Tanada. Ahtna used/use all of these rivers to acquire salmon. Salmon were the primary food resource used by the Ahtna, who processed thousands of fish in the summer for food in the winter.

Recent archeological research has determined that human populations occupied the shoreline of Lake Atna approximately 10,000 years ago (Reinghaus and Biddle 2018). Indicative archeological items demonstrate Ahtna have been present in the Copper River valley for about 5000 years (Potter 2008). Most Ahtna followed an annual cycle in which they lived in villages near the Copper River in summer, where they put up salmon, traveled up the river valleys to hunt caribou, moose, and sheep in the fall, and returned to their villages with their harvests for the winter months. Ahtna society consisted of lower, middle, upper, and interior or western divisions. The first three reference their position in the Copper River, while the latter division occupied lands in the upper Susitna River valley. Ahtna were/are born into one of eight matrilineal clans that were/are positioned in two moieties - Raven and Seagull. Individuals were required to marry a person from a clan from the other moiety. Long-term interclan marital ties were characteristic, as they established and maintained critical relations necessary for the conduct of potlatch ceremonies, key events in sustaining the continuity and governance of Ahtna society. Social units, called tribes or bands, consisted of a primary clan that was considered the owner of the territory and those who married into it. Early EuropeanAmerican explorers and prospectors in the region observed that tribal territory and boundaries were well-known, and other tribes could not enter without permission or invitation for "if they did, it meant war" (Simeone 2018:31). Current elder leader Wilson Justin views clan territories as multidimensional spaces consisting of people, animals, plants, earth, water, and air-it is a landscape lived in and with, where "exclusive use and jurisdiction [has been exercised] over many, many, many, thousands of years" (Simeone 2018:31). Governance of Ahtna society was conducted through the authority of denae and kaskae. Denae were clan headmen who were the highest-ranking person of the local clan and presided over the larger villages. Denae controlled distinct territories and made decisions about the use of an area and its resources (Simeone 2018:101). Kaskae were below the denae and presided over smaller villages. There were seventeen Ahtna denae, with titles designating the locations of their jurisdiction (Simeone 2018:100).

Ahtna viewed/view animals and fish as spiritual forms who gave/ give themselves to humans, were/are controlled by powerful spiritual beings, and with whom relations were/are governed by an elaborate system of rules and proscriptions called 'engii, a term that is synonymous with power (Simeone et al. 2007:83). Mythic charters established compacts specifying how the reciprocal relationship between animals and humans was to be conducted and authorizing certain forms of human use subject to conditions of appropriate action. The 'engii for salmon was codified in an account of a young boy, Bac'its'aadi, who disappears from a salmon cache and later returns in the river the next year as a small king salmon. When he is taken by his relatives, the "boy...tells them the story about living with the fish and what they don't like and what they do like" (Simeone 2018:74). His teachings are the foundation for the salmon 'engii that emphasize respectful treatment as the basis for the return of salmon "only to those who work on them carefully" (Simeone 2018:75).

Governance of the relationship between people and salmon depended on teaching young people how to think and behave. Young people were taught the mythic charters and their significance, were required to observe and learn how to behave in general and in regard to salmon specifically, what were the appropriate behaviors that must be carried out to show respect to salmon. Particularly significant were learning the crucial behaviors, welcoming songs and dances that were to be conducted on the arrival of the salmon each year (Justin 2018, personal communication). Successful engagement with salmon required that all Ahtna participants must act in appropriate ways. Elders observed the behaviors of young people, and only when they had demonstrated a full comprehension of the teachings and conducted themselves in appropriate ways without guidance, were they considered "citizens," meaningfully empowered members of the clan able and required to fully participate (Justin 2017, personal communication).

Ahtna governance of salmon and relations with salmon involve a number of elements. Constant acquisition of observations about salmon and environment was ongoing. The information acquired was shared and recorded in detailed accounts of long- 
term changes to salmon runs found in Ahtna oral traditions (Simeone and McCall 2007). Ahtna understood/understand the salmon life cycle, as they observed it and had seven terms for different stages from eggs in redds to spawning stage and death (Simeone 2018:75). Terminologies identified all five species of salmon as well as varieties of species, such as the large sockeye originally returning to Tanada Creek and harvested at Natelde (also known as Batzulnetas), an important fishing site in the upper Ahtna territory.

Most Ahtna salmon harvests took place on the Copper River proper, from the shore or fishing platforms using dipnets (Simeone 2018:57). Only a few locations in the smaller shallower tributaries in the northern area were suitable for weirs and basket traps. Ahtna throughout the Copper River preferred males over females because they were "larger and fatter" (Simeone and Kari 2002:168). Of the 88 documented traditional Ahtna salmon fishing locations in the Copper River system, 17 of them belonged to specific denae (Simeone 2018).

Approximately a month before the expected arrival of salmon at Batzulnetas, men of the local group would travel the course of Tanada Creek and tributaries to Tanada Lake where sockeye were known to spawn and remove any beaver dams they found (Justin 2018, pers. comm.). At Batzulnetas, the spiritual welcoming of the return of the salmon would be undertaken as a moral obligation conducted by the kaskae. During the period of waiting for the arrival of salmon, loud noises were prohibited, speaking softly was required, no entry into water was allowed, people moved slowly and with limited motion, and rounds of sweat bath cleansing and purification were undertaken (Justin 2017, personal communication). Ahtna believed that "salmon return to their natal streams to give themselves for harvest...if the fish are not used, they will not return to their natal streams" (Simeone and McCall 2007:40).

When the first salmon appeared, people wore special clothing as they performed welcoming songs and dances that were to be conducted on the arrival of the salmon each year (Justin 2018, personal communication). Following these ceremonies, the conduct of salmon harvest was placed under the direction of a "salmon boss," who would be given the authority and responsibility by the denae to ensure social obligations were met and that all eligible fishing parties had a spot. Harvest supervision included timing on placement of the weir, overseeing the basket traps to ensure they were emptied and that no wastage occurred, monitoring harvest levels and deciding when to open the weir to allow the salmon to ascend to the lake (Simeone 2018:109). Ahtna were enjoined to take only what was necessary and had target goals, measured in bales of fish, that were adjusted based on need and environmental conditions (Simeone and Kari 2002:169). Ahtna salmon governance was designed to serve the entire tribe through providing access, sharing, exchanging, and bartering and to seek equity by avoiding greed and hoarding (Justin 2018, personal communication).

The denae periodically decided that certain streams should or should not be fished in a given season. This was done because the run was limited and could not support a family, the previous cycle run had been very low, or environmental factors were not favorable (Justin 2018, personal communication). For example, there was a small stream with a limited king salmon run on the east side of the Copper River above Chistochina that people were rarely allowed to obtain fish from unless authorized. Ahtna governance of salmon and people through spiritual obligations, empirically grounded observations, and highly developed controls over fishing sites and fishing practices-under the leadership of well-respected leaders - was successful in sustaining the salmon runs and their use by Ahtna people for thousands of years.

The Central Yup'ik - Salmon Relationship (Written and reviewed by Steve Langdon and Mike Williams (Yup'ik))

The Central Yup'ik were the most numerous of Indigenous Alaskans at the time of contact (Langdon 2014). They occupied the region from the Nushagak River in Bristol Bay north and west to the coast of Norton Sound. In addition, Central Yup'ik populations were established in villages over 100 miles up the Kuskokwim and Yukon River. For Central Yup'ik living on the primary rivers of the region-Nushgak, Togiak, Kanektok, Kuskokwim and Yukon - salmon were/are primary resources. In Bristol Bay, sockeye salmon were the most important species, whereas on the Kuskokwim and Yukon, king, chum, and to a lesser extent, coho salmon were the most important. Marine mammals on the coast and terrestrial mammals upriver were significant additional resources where they were available.

Limited archeological evidence from the Bering Sea coast indicates that Central Yup'ik peoples were likely to have been present in the coastal area of the region about 4000 years ago, gradually expanding south and east up the main rivers and into Bristol Bay (van Stone 1967). Central Yup'ik society was organized on a village and local group basis, with approximately 14 local group units identified by the suffix miut ("people of") being found in the region. Each local group consisted of several intermarrying and ceremoniously interacting villages; typically, a pair of villages participated in reciprocal hosting of ceremonies at which the other village would be the invited guests. Local groups and their component villages had well-established territories for fishing, hunting, and gathering activities. Boundaries of the local group territories were well known, respected, and protected. Extended intermarrying families owned fishing sites and camps where they went each summer to catch and process salmon, returning in the fall to their villages. Salmon fishing was done primarily by set nets, dipnets, and traps. Each village had a ceremonial or men's house, qasigiq, where the adult men lived, while their wives and children had smaller separate dwellings that the husbands visited. In this ceremonial space, the Central Yup'ik conducted a range of social and spiritual ceremonies that were the lubricant and glue facilitating relations among humans and between humans and the spiritual world (Fienup-Riordan 1983, Meade and Fienup-Riordan 1996).

Central Yup'ik believe that all living and other forms have spirits that are sentient, attentive, communicative, and volitional. A central concept in organizing their understanding of existence is Ella (Kawagley 1995:15) or Ellampiim yua, translated as "Spirit of the Universe." This concept conveys the essential quality of awareness and the preferred state of harmony in the universe. The spiritual heads of fish and animal species determined/determine how the individual members of species would/will distribute or give themselves to different human populations depending on how they were treated. Salmon were/are under this general 
framework of how species were/are to be treated. Central Yup'ik spiritual ceremonies were conducted under the direction of the angalquk (shaman) who had powers to communicate with spiritual forces of the fish and animals in the land of the dead. He designed and constructed masks based on his spiritual visions that he or others wore during the songs and dances the people performed during the "Season of the Drum" when many ceremonies occurred. Masks typically represented Ella as an oval form inside or around which were attached small images of fish and animals (Fienup-Riordan 1996). The masks were worn and performed during the dances and songs that were collectively conducted by the people of the community. The ceremonies were intended to honor and demonstrate interest to the spirits of the fish and animals "to insure the presence [and return] of the...animals that the people needed for survival" (Meade and Fienup-Riordan 1996:25). These activities were referred to as agayu or "our way of making prayer" (Fienup-Riordan 1996, Meade and Fienup-Riordan 1996). Central Yup'ik elders referred to the purposes of these prayers as "clearing the path" for the fish and animals to return (Meade and Fienup-Riordan 1996:29). Central Yup'ik believe that fish and animals presented themselves to people to be harvested and further that it was their moral obligation to take those that presented themselves (FienupRiordan 1990). Not to do so would be taken as an insult by fish and animals, who then would not return to those unwilling to harvest (Fienup-Riordan 1990). Furthermore, fish are observant and attendant to the capabilities of Central Yup'ik harvesters' abilities to provide respectful, clean, safe conditions for their processing and storage. These principles were/are taught to boys and girls with the admonition that failure to uphold them would result in the salmon not returning to give themselves to the people and the people would starve. Respectful taking was fundamental to the spiritual relationship between humans and other species.

For Central Yup'ik, the continuity of relations between themselves and salmon and respectful adherence to moral obligations they regarded as essential to their survival were collective responsibilities. Through these spiritual beliefs, ceremonial actions, and practices of careful, respectful use, the Central Yup'ik maintained relationships with salmon over thousands of years

\section{Inequities in the Salmon-People System}

Alaska Natives, despite their long-term relationship with salmon, have been largely left out of any decisions related to salmon management. This is unfortunate for the salmon, for salmon people, and for the State of Alaska, which depends on salmon as a pillar of the state economy. The forces of colonization have been hostile to Alaska Native people and have led to our current situation, where we find ourselves in a position where our deepest relationships and expressions of spirituality are at times severed by limited or zero openings to live our way of life through the timeless exercise of fishing for salmon..

Salmon play an important role today, as they always have, in the lives and cultural foundation of Alaska Native individuals, families, and peoples. Children are raised with salmon as a central presence, another relative, which one must care for, share with, and most of all, respect. This timeless relationship has created a strong

\begin{abstract}
foundation, which until more recently children could depend on. Yet, the current management system, which has largely disenfranchised Alaska Native people, has resulted in egregious dispossession of fishing rights and ways of life. Generational knowledge, passed down from grandmas, grandpas, aunties, uncles, and parents are left in the shadows when there are no fish in the net or worse, no net in the river. Salmon give reason and meaning to life in a very foundational sense and teach children how to view the world from the lens of their cultural values. Justin and Black (2019)
\end{abstract}

Inequities in the salmon-people system have emerged as a critical point of consideration looking back and looking forward in this review of social and cultural dimensions of salmon systems in Alaska. Pronounced inequities are evident in the relatively recent history of settler colonialism and industrial extraction. In current times, the criminalization of traditional hunting and fishing ways of life (often called subsistence in the Alaska context) and the dramatic loss of Indigenous and rural commercial fishing rights are two of the pressing inequities facing many regions throughout the state. Taken together, criminalization and dispossession have had a dramatic effect on the social, cultural, and economic wellbeing of Alaska's first salmon stewards. The governance of salmon in Alaska is complex and reviewed in Langdon (2019).

\section{Criminalization of traditional ways of life}

In our State of Alaska Salmon and People project working group meetings, the life experiences of Indigenous team members that were shared revealed the deep pain caused by institutionalized racism and colonial Eurocentric worldviews. In the introduction to this paper, we hear Dr. Liza Mack (Unangax) tell the story of being a young girl hiding in the grass with her grandfather as a state enforcement plane flies overhead. Alaska Native Peoples learn from a young age that the very foundation of Indigenous culture and way of life is threatened by settler jurisdiction attempting to control access and limit self-determination. Indigenous working group members shared many personal stories like this one. Some related to the hardships caused by the Chinook salmon declines on the Kuskokwim and Yukon Rivers beginning in the late 1990s (see Schindler et al. 2013), the burden of conservation placed on subsistence over industrial fisheries, and the lack of power that Indigenous Peoples had over decision making and management. Coauthor Jonathan Samuelson, a young Yup'ik and Athabascan fisherman, discussed how hard the state regulatory subsistence fishing closures were to experience at fish camps along the Kuskokwim River.

\section{I feel like a criminal... I feel sick to my stomach. This is not right. We're just sitting here, and seeing the fish, watching them go by. Then my cousin finally comes [ to fish camp] with all her kids. and they don't even get to learn...so we had this paradigm shift because I had heard stories like this from downriver and never knew actually how it made them feel. Jonathan Samuelson, SASAP Well-being Working Group Meeting, Santa Barbara, California, USA, 2017}

Alongside these stories of criminalization, participants in this project also shared stories of resistance. For example, the fishermen of the Kuskokwim River protested subsistence fishery closures by fishing openly as a deliberate act of resistance. In June 
2012, over 50 people were issued citations, with their nets being seized or cut (Stevens and Black 2019). These citations and the limitation of traditional practices have had deeply negative effects on individual and community well-being.

These 55 fishermen (who were cited)... they're still going through the depression, the anxiety and still going through the healing process of 2012. Andit's still hanging around our communities...there's got to be a way to avoid criminalization of our way of life...

...It hurts inside of how we were used to...we were taught to feed our families from the resources, but the state policy and the federal policy didn't allow us to do that. So in turn we see suicides, highest suicide rates in the nation, highest domestic violence and alcohol abuse and substance abuse. Mike Williams, SASAP Well-being Working Group Meeting, Santa Barbara, California, USA, 2017

This action in 2012 in part prompted the unification of all of the Tribes of the Kuskokwim River to form the Kuskokwim River Inter-Tribal Fish Commission (KRITFC) (Brelsford 2019; KRITFC 2019). The Commission has a formal agreement with the U.S. Department of the Interior to comanage salmon resources of the Kuskokwim. In 2019, for example, the Commission, along with the U.S. Fish and Wildlife Service, advocated for increased conservation (less fishing). The State of Alaska did not support this proposal for higher escapement (less harvest) (see KRSM 2019). This example validates that the Indigenous Peoples of the Kuskokwim River use their/our comanagement responsibility to advocate for the long-term health of the salmon, not for short-term increased allocation. This is a demonstration of the need and desire for traditional stewardship principles to be applied to salmon management, especially in times of scarcity.

These stories are not limited to the Kuskokwim River region. Criminalization of traditional ways of life is prevalent among Indigenous communities of the Yukon River, along the Copper River, across the Kodiak Archipelago, within Bristol Bay, the Aleutians, and throughout the Southeast (see Stevens and Black 2019). With the criminalization of traditional Indigenous hunting and fishing practices come humiliation, anger, fear, desperation, shame, frustration, devastation, and coping attempts. The highly publicized case of former State Senator and Tlingit fisherman Albert Kookesh is one example of this. Senator Kookesh was given a citation for "overfishing" in 2009. Kookesh, a lawyer, wanted to highlight the injustices of state subsistence management in his region in Southeast Alaska that allowed only 15 fish per family per year.

I didn't do it to break the law. I didn't do it to offend anybody. I did it to challenge that premise, 15 fish per family per year...that is one and a half fish a month, or less... Let me see any of you try and live the life of a whole salmon season, a whole winter on 15 fish. Especially if you have a family of ten or five...I wanted to challenge that forever...

The progress of an Alaska Native in Alaska can be measured by our success in the courts. Nobody ever gave us anything. We had to sue for it...I hope you can understand as to why I challenged it. I thought that wasn't fair. I thought it was not right. I feel, being a senator and former representative of the house, that laws are going to continue to evolve in Alaska. Everything you all do, everything we all do collectively is going to help get us to a place where we want to be eventually, especially when it comes to our salmon. So, these kinds of cases aren't mean cases, they are trying to develop the law to where it should be. Albert Kookesh, Salmon and Society Meeting, Anchorage, Alaska, USA, 2016

Senator Kookesh withstood personal and financial hardship over the course of 7 years of litigation (Kookesh 2016, personal communication). His story demonstrates the inequities (born of colonization, racism, and oppression) that are deeply embedded within the legal, social, cultural, political, and economic institutions of salmon science and management in Alaska today. Given how central salmon are to traditional ways of life, with a high percentage of households across the state relying on salmon subsistence fisheries (Fig. 3), resolving these tensions and traumas is paramount for the state to move toward a just and sustainable future.

Fig. 3. Percentage of households by community who harvest salmon for subsistence (Clark et al. 2018).

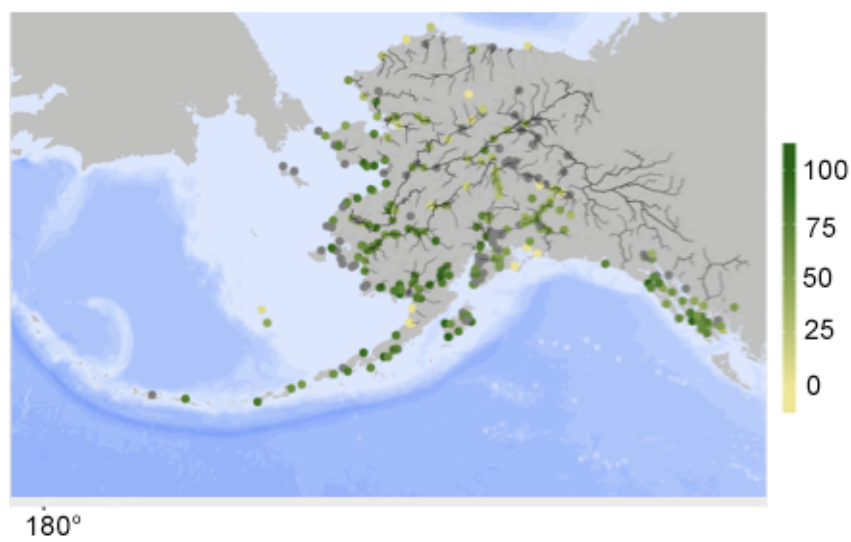

Dispossession of commercial fishing rights

Another example of a fundamental inequity evident in our review of social and cultural dimensions of salmon systems in Alaska is the dramatic alienation of Alaska Native commercial fishing rights, threatening village sustainability and violating an international ethic of Indigenous peoples' self-determination and right to their cultural lifeways (United Nations 2007). Alaska is facing a growing problem of commercial fisheries access that obstructs the healthy succession of fishing as an economic and cultural mainstay across the state (e.g., Ringer et al. 2018). This is especially pronounced within Indigenous communities, highlighting the inequity. For example, the six Sugpiaq [Alutiiq] villages in the Kodiak Archipelago have reached a crisis, due to lost fisheries access and the cumulative impacts of restricted access management. Within just one generation, there has been a dramatic decline in access to salmon fishing livelihoods. There has been an $85 \%$ decrease in the number of young people with 
rights to fish for salmon commercially, the foundational fishery for this region (Donkersloot and Carothers 2016). Figure 4 shows these declines in communities across the state.

Fig. 4. Change in percentage of number of permits per capita by community (1990-2016) (Clark et al. 2018).

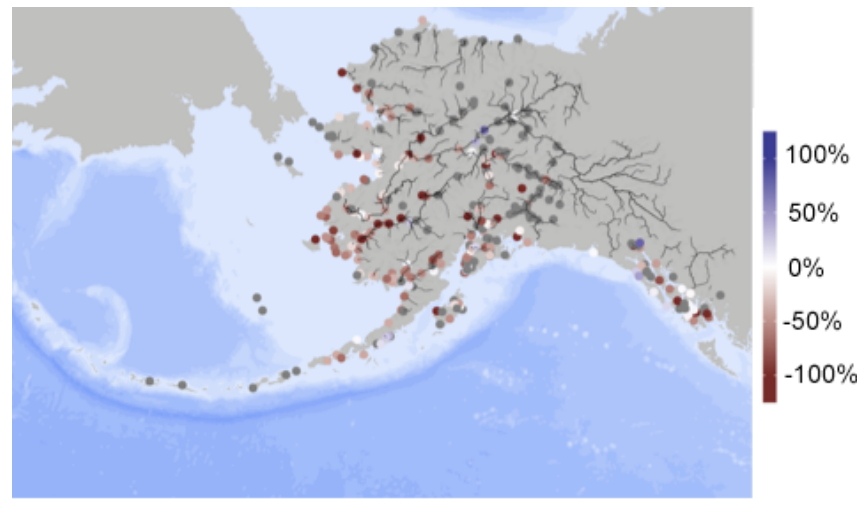

Declines in fishing access greatly affect community life and sustainability. Communities are depopulating and facing social problems. Schools are closing. In a recent study of secondary school students in the village of Ouzinkie, less than $25 \%$ of youth have ever had any commercial fishing engagement (despite nearly all students having multigenerational family ties to fishing); less than $10 \%$ of students in Ouzinkie see a positive future for young people in their community (Coleman et al. 2018). Ouzinkie is just one example of an Indigenous community based on a fishing way of life where lost access to their fisheries threatens future viability. For the Sugpiat, whose culture and economy has been built around fishing for 7500 years, this recent dispossession is profoundly devastating. Moreover, the Sugpiat have stewarded these fisheries for thousands of years, yet have been dispossessed from their right to fish and largely left out of management decisions and power dynamics (see Krupa et al. 2018, 2019).

These inequities born of institutional racism lead to a rapid downward spiral, where feelings of depression, anxiety, and other negative coping mechanisms prevail. This story shared by one of our working group members and coauthors, Freddie Christiansen, from the Sugpiaq village of Old Harbor on Kodiak Island, helps to connect the loss of fishing rights, loss of traditional livelihoods, and the downward spiral. His experience centers on the passage of the Alaska Limited Entry Act of 1973 that limited and commodified the right to fish for salmon, the lifeblood of the Indigenous fisheries for the Kodiak region.

Growing up as a kid in the village, we were very attentive. We didn't have a whole bunch. We didn't have distractions. We didn't have TV...but what we did have is each other. And we [had] our toys made by our Elders, or brothers. We had fishing boats-little sailors, every one of us. And our playground was not an actual playground. It was up the hill or down the beach at low tide. There was always a connection between us and the marine environment and the environment naturally, without anybody telling us that was what we had. That was our playground. And I am sitting here trying to figure out what is it...what is it going to take to capture these guys' attention that the status quo isn't working. I can give you examples.

My example, is growing up as a kid...these nine boys, all of us were brothers. We were cousins, we were best friends, we were neighbors, we all had our little boats. As far back as I can remember, every one of those guys' dream was to become a skipper or an owner of a boat. And it took me [until I was] 30, 35 years old to realize what occurred in that time frame because a lot of things happened. Limited entry, IFQs [individual fishing quotas], [the Exxon Valdez ] oil spill. It was just nothing good. But the limited entry aspect of it...I think it was passed in 1971 or 1972... They talked about it when I was 18, 19 years old... So all of us boys, by the time limited entry passed, I could see the change in behavior, not only within myself but everybody that was in this group. Knowing that your dreams of becoming a skipper, your aspirations are thrown in the garbage can.

And I remember the State of Alaska sending people into a village...[to sign] a petition supporting the implementation of limited entry. I remember that, and I was young but I was paying attention. And the Elders signed it not knowing what the qualifying years were yet. '67 to '71... am I right? '67 to '71...that's the qualifying years. You know half of the Elders that signed it didn't get limited entry permits because they retired. And '64 and '65...it was before ' 67 and then I knew from that point on, that after they didn't get their permits that something was wrong with the program, not realizing that none of us are going to become skippers. You know none of us. We had to have, \$15,000 or \$30,000 to go buy a license. And I was the one of the determined ones. I wasn't going to wash dishes for the rest of my life on my brother's boat. Because of fishing and what my brother said, and to have people throughout my life to encourage me to move forward you know, no matter what. It is a barrier, it's a stumbling block; you just get up and keep going on. And so I was raised that way and so were the other boys.

But the hopes and dreams of theirs, and I don't know, in about a year I saw them change. By the time they fully implemented limited entry, I had realized that by 15, 16, to 17 years old if I am going to be a skipper I have to figure out a way to buy a permit. And so, I was one of the ones that was fortunate [because] one of my cousins was willing to sell his permit to me for $\$ 28,000$ and here I am 17 years old. I go fishing with my brothers, Imake...I remember when we made $\$ 17,000$ in 1977. $\$ 17,000$ is a lot of money. And that was a year that I was actually able to keep a lot of the money, but still help mom and dad to be able to buy groceries. I gave $\$ 12,000$ to buy that permit, but I was concerned about how I was going to help my cousins and the other group. And it just...nothing was going to work. There was a couple of the boys that were going to acquire their dads' [permits] but most of our families had...six to ten boys in the family and you have to give one permit and decide who is going to get it? And so that was difficult on the parents, too. And so 
anyways, I get my permit, I am sailing, I am a skipper but the other eight aren't; and I'll tell you by the age of 35 years old, that four of them were dead. And I truly believe that limited entry implementing program did that to them. I truly believe that. That was my experience.

...I tell this story because it's tied to salmon. It's not just about going out and making \$200,000. You know we have had our horrible years, like salmon fishing last year. You know nobody made any money. But guess what, we are all still there. Yes, there was half of us that weren't worksatisfied, but still there was that culture aspect that was satisfied. But the monetary side wasn't. But none of [us] quit, all of [us] went back hoping that ... there was going to be fish this year, and there was. I really think any resources that are adjacent to a community-there has to be a way to ensure that those people there, adjacent to that community, whether it be guiding, whether it be commercial fishing... whatever, the resources are there. But those people that live next to that resource have first access to it. It's just a no brainer and to me, I've brought people down to Old Harbor, to educate them you know...to stay, you know because people are trying to say well how can we get to these guys [to make them understand]? Basically Elders are trying to say...And I'll just say just tell them the truth. Somebody is eventually going to listen. Billy Frank told me that. Never quit. Just keep going... I get frustrated but I don't quit. I think of all my buddies that I grew up with and are no longer living, whether it was from suicide or whether it was from, overdose of drugs or whatever it was. I really believe that those guys, they wanted to be skippers. They would have had families. They would be here today. I really believe that. Freddie Christiansen, SASAP Wellbeing Working Group Meeting, Santa Barbara, California, USA, 2017.

This story demonstrates some of the experiences that Indigenous Peoples and communities have faced after their access to traditional and cultural livelihoods was taken away, as well as the strong cultural value of perseverance in the face of change and the desire to rectify deep-seated problems.

In both of these examples - criminalization of Indigenous ways of life and dispossession of fishing access — we see racist policies that have deep and lasting impacts on individuals, families, and communities and their/our wellness. An entire generation has grown up having to contend with these inequities and injustices. Communities grieve a lost generation who has been alienated from their Indigenous ways of life.

\section{CONCLUSION}

Alaska's salmon and Indigenous Peoples have been closely entwined for millenia. Given this lengthy period of coinhabitation, cultures such as the Tlingit, Ahtna, and Central Yup'ik, reviewed here, would of course have had well-developed knowledge and stewardship practices. Communities could have easily decimated salmon populations (see Langdon 2019 for population and harvest estimates demonstrating this point). But they did not do that. They effectively stewarded salmon across Alaska for millenia. It is a testament to the ongoing prevalence of institutionalized racism and Eurocentrism that this stewardship and depth of knowledge are rarely acknowledged, or drawn upon, in western science and management processes in Alaska today. This Indigenous history and the contemporary relations and fractures are of key importance to understand the social and cultural dimensions of fisheries in Alaska. Given these deep relationships and recent dispossessions, there is a pressing need to address Indigenous rights to fish in Alaska. In our larger work for this project, we see persistent erasure of Indigenous history and relationships (Donkersloot et al. 2020). The dispossessions we have described here are not inevitable, but the result of specific policies and management approaches that have shifted relationships (Whyte 2018). For example, in subsistence fisheries management, the temporal regulations and closures on the Yukon and Kuskokwim affect cultural and spiritual ways of life (Voinot-Baron 2020). In commercial fisheries management, the right to fish has been limited and commodified and is available only to those who are wealthy or have access to wealth. Flexible and adaptive small-scale livelihood fishing ways of life are threatened. Our review and working group dialogs have helped to gather the experiences that Indigenous People and communities have faced after generations of criminalization, restriction of traditional ways of life, the implementation of policies that have not served their/our communities well-as well as the strong cultural value of perseverance in the face of change and the desire to rectify deep-seated problems. We hope that this paper is a small step toward greater understanding and recognition of the pluralism of worldviews, cultures, and governance approaches to salmon across the state; and how the assumed homogeneity of values and practices of the dominant settler state has caused deep hardship and stress for Indigenous Peoples and their/our relations with salmon. We hope this understanding and recognition can bring about a return of sovereignty for Indigenous Peoples to govern their relations with salmon and other beings as dictated by Indigenous governance systems, not those of settler colonial states.

Responses to this article can be read online at: https://www.ecologyandsociety.org/issues/responses. php/11972

\section{Acknowledgments:}

We offer our humble gratitude to Alaska Natives Peoples, Alaska's first and forever stewards. We thank the State of Alaska Salmon and People Project leads Ian Dutton, Frank Davis, and Peter Westley for their vision and oversight; working group members Caroline Brown and Jim Fall, both of the Alaska Department of Fish and Game; Sarah Warnock and Katherine Schake for their tireless efforts and logistical support throughout the project; National Center for Ecological Analysis and Synthesis staff, especially Jared Kibele, Jeanette Clark, Ginger Gillquist, Matt Jones, and Jenny Seifert.

\section{Data Availability:}

We refer readers to SASAP 2019 which contains details on accessing data. 


\section{LITERATURE CITED}

Brelsford, T. 2019. The Kuskokwim Chinook salmon crisis and the emergence of the Kuskokwim River Inter-Tribal Fisheries Commission. In State of Alaska Salmon and People (SASAP). State of Alaska salmon and people. National Center for Ecological Analysis and Synthesis (NCEAS), Santa Barbara, California, USA. [online] URL: https://alaskasalmonandpeople.org/region/ kuskokwim/

Clark, J., R. Donkersloot, C. Carothers, and J. Black. 2018. Sample indicators of well-being in Alaska. Knowledge Network for Biocomplexity, National Center for Ecological Analysis and Synthesis (NCEAS), Santa Barbara, California, USA. https:// doi.org/10.5063/F1XK8CVG

Donkersloot, R., and C. Carothers. 2016. The graying of the Alaskan fishing fleet. Environment: Science and Policy for Sustainable Development 58(3):30-42. https://doi. org/10.1080/00139157.2016.1162011

Donkersloot, R., J. C. Black, C. Carothers, D. Ringer, W. Justin, P. M. Clay, M. R. Poe, E. R. Gavenus, W. Voinot-Baron, C. Stevens, M. Williams, J. Raymond-Yakoubian, F. Christiansen, S. J. Breslow, S. J. Langdon, J. M. Coleman, and S. Clark. 2020. Assessing the sustainability and equity of Alaska salmon fisheries through a well-being framework. Ecology and Society 25 (2): 18. https://doi.org/10.5751/ES-11549-250218

Fienup-Riordan, A. 1983. The Nelson Island Eskimos. Alaska Methodist University Press, Anchorage, Alaska, USA.

Fienup-Riordan, A. 1990. Original ecologists? The relationship between Yup'ik Eskimos and animals. Pages 167-191 in A. Fienup-Riordan. Eskimo essays: Yup'ik lives and how we see them. Rutgers University Press, New Brunswick, New Jersey, USA.

Fienup-Riordan, A. 1996. The living tradition of Yup'ik masks. University of Oklahoma Press, Norman, Oklahoma, USA.

Halffman, C. M., B. A. Potter, H. J. McKinney, B. P. Finney, A. T. Rodrigues, D. Y. Yang, and B. M. Kemp. 2015. Early human use of anadromous salmon in North America at 11,500 y ago. Proceedings of the National Academy of Sciences 112(40):12344 12348. https://doi.org/10.1073/pnas. 1509747112

Justin, W., and J. Black. 2019. An Indigenous forward. In State of Alaska Salmon and People (SASAP). State of Alaska salmon and people. NCEAS, Santa Barbara, California, USA. [online] URL: https://alaskasalmonandpeople.org/wp-content/uploads/2019/03/ An-Indigenous-Forward.pdf

Kawagley, O. 1995. A Yupiaq worldview: pathway to ecology and spirit. Waveland Press, Prospect Heights, IIlinois, USA. https:// doi.org/10.1215/9780822390831-023

Krupa, M. B., M. Cunfer McCarthy, and S. J. Clark. 2019. Who's winning the public process? How to use public documents to assess the equity, efficiency, and effectiveness of stakeholder engagement. Society and Natural Resources 33:6121-633. https:// doi.org/10.1080/08941920.2019.1665763

Krupa, M. B., M. M. C. Cunfer, S. J. Clark, and E. O'Dean. 2018. Resurrecting the public record: assessing stakeholder participation in Alaska's fisheries. Marine Policy 96:36-43. https://doi.org/10.1016/j.marpol.2018.07.010
Kuskokwim River Salmon Management Working Group (KRSM). 2019. Meeting Packet 06/05/2019. [online] URL: https://www.adfg.alaska.gov/index.cfm?adfg=commercialbyareakuskokwim.kswg

Kuskokwim River Inter-Tribal Fish Commission (KRITFC). 2019. [online] URL: https://kritfc.org/

Langdon, S. 2019. Governance and Subsistence Working Group. In State of Alaska Salmon and People (SASAP). State of Alaska salmon and people. National Center for Ecological Analysis and Synthesis (NCEAS), Santa Barbara, California, USA. [online] URL: https://alaskasalmonandpeople.org/working-group/governanceand-subsistence/

Langdon, S. 2014. Native people of Alaska: traditional living in a northern land. Fifth edition. Greatland Graphics, Anchorage, Alaska, USA.

Langdon, S. 2006a. Tidal pulse fishing: selective traditional Tlingit salmon fishing techniques on the west coast of the Prince of Wales Archipelago. Pages 21-46 in C. Menzies, editor. Traditional ecological knowledge and natural resource management. University of Nebraska Press, Lincoln, Nebraska, USA.

Langdon, S. 2006b. Traditional knowledge and harvesting of salmon by HUNA and HINYAA LINGIT. Fisheries Information Service Report 02-104. U.S. Department of Interior, Fish and Wildlife Service, Office of Subsistence Management, Anchorage, Alaska, USA.

Mack, L. 2019. Unangam Unikangis: Aleut stories of leadership and knowledge. Dissertion, University of Alaska Fairbanks. Fairbanks, Alaska, USA.

Meade, M., and A. Fienup-Riordan. 1996. Agayuliaarput: our way of making prayer-masks and the stories they tell. University of Alaska Press, Fairbanks, Alaska, USA.

Potter, B. 2008. Exploratory models of intersite variability in mid and late Holocene sites in central Alaska. Arctic 61(4):407-425. https://doi.org/https://doi.org/10.14430/arctic49

Potter, B. A, J. D. Reuther, V. T. Holliday, C. E. Holmes, S. Miller, and N. Schmuck. 2017. Early colonization of Beringia and northern North America: chronology, routes and adaptive strategies. Quaternary International 444b:36-55. https://doi. org/10.1016/j.quaint.2017.02.034

Reid, A. J., L. E. Eckert, J.-F. Lane, N. Young, S. G. Hinch, C. T. Darimont, S. J. Cooke, N. C. Ban, and A. Marshall. 2020. Twoeyed seeing": an Indigenous framework to transform fisheries research and management. Fish and Fisheries: in press. https:// doi.org/10.1111/faf.12516

Reinghaus, L., and G. Biddle. 2018. Late Pleistocene archeology of Wrangell-St. Elias National Park and Preserve: it exists! Poster presented at the 45th Annual Meeting of the Alaska Anthropology Association Annual Meeting, 21-24 March 2018, Anchorage, Alaska, USA.

Ringer, D., C. Carothers, R. Donkersloot, J. Coleman, and P. Cullenberg. 2018. For generations to come? Shifting baselines and privatization paradigm impacts in Kodiak Archipelago's 
commercial fisheries and livelihoods. Marine Policy 98:97-103. https://doi.org/10.1016/j.marpol.2018.09.009

Schindler, D, C. Krueger, P. Bisson, M. Bradford, B. Clark, J. Conitz, K. Howard, M. Jones, J. Murphy, K. Myers, M. Scheuerell, E. Volk, and J. Winton. 2013. Arctic-YukonKuskokwim chinook salmon research action plan: evidence of decline of chinook salmon populations and recommendations for future research. Prepared for AYK Sustainable Salmon Initiative. Anchorage, Alaska. [online] URL: https://www.aykssi.org/wpcontent/uploads/AYK-SSI-Chinook-Salmon-Action-Plan.pdf

Simeone, W. 2018. Ahtna: the people and their history. Ahtna, Inc., Glenallen, Alaska, USA.

Simeone, W., and J. Kari. 2002. Traditional knowledge and fishing practices of the Ahtna of the Copper River, Alaska. Technical Paper No. 270. Alaska Department of Fish and Game, Division of Subsistence, Juneau, Alaska, USA.

Simeone, W., and E. McCall. 2007. Ahtna knowledge of long-term changes in salmon runs in the Upper Copper River drainage, Alaska. Technical Paper No. 34, Alaska Department of Fish and Game, Division of Subsistence. Anchorage, Alaska, USA.

Simeone, W. E., E. McCall Valentine, and S. Tuttle. 2007. Ahtna knowledge of long-term changes in salmon runs in the Upper Copper River drainage, Alaska. Technical Paper No. 324: 144. Alaska Department of Fish and Game, Juneau, Alaska, USA.

Smith, J. 2011. An update on intertidal fishing structures in southeast Alaska. Alaska Journal of Anthropology 9 (1):1-26.

State of Alaska Salmon and People (SASAP). 2019. State of Alaska salmon and people (SASAP). National Center for Ecological Analysis and Synthesis (NCEAS), Santa Barbara, California, USA. https://alaskasalmonandpeople.org/

Stevens, C., and J. Black. 2019. I am a criminal: criminalization of Indigenous fishing practices. In State of Alaska Salmon and People (SASAP). State of Alaska salmon and people. National Center for Ecological Analysis and Synthesis (NCEAS), Santa Barbara, California, USA. [online] URL: https://alaskasalmonandpeople. org/region/yukon/

Thornton, T., D. Deur, and H. Kitka. 2015. Cultivation of salmon and other marine resources on the northwest coast of North America. Human Ecology (43):189-199. https://doi.org/10.1007/ $\underline{\mathrm{s} 10745-015-9747-\mathrm{Z}}$

United Nations. 2007. Declaration on the rights of Indigenous peoples. United Nations Department of Economic and Social Affairs, Indigenous Peoples, New York, New York, USA. [online] URL: https://www.un.org/development/desa/Indigenouspeoples/ declaration-on-the-rights-of-indigenous-peoples.html

van Stone, J. 1967. Eskimos of the Nushagak River. An ethnographic history. University of Washington Press, Seattle, Washington, USA.

Voinot-Baron, W. 2020. A bitter taste of fish: the temporality of salmon, settler colonialism and the work for well-being in a Yupiaq fishing village. Ecology and Society 25(2): 4. https://doi. org/10.5751/ES-11408-250204
Whyte, K. P. 2018. Food sovereignty, justice and indigenous peoples: an essay on settler colonialism and collective continuance. Pages 345-366 in A. Barnhill, T. Doggett, and A. Egan, editors. Oxford Handbook on Food Ethics. Oxford University Press, Oxford, UK. https://doi.org/10.1093/ oxfordhb/9780199372263.013.34 


\begin{tabular}{|c|c|c|}
\hline Theme & Description & Example references \\
\hline Mixed economies & $\begin{array}{l}\text { Subsistence harvest of wild resources exists in } \\
\text { consistent balance with cash-generating } \\
\text { activities; interactions between the two include } \\
\text { customary trade and barter, the use of cash to } \\
\text { purchase equipment, fuel, and supplies for } \\
\text { subsistence and the practice of sharing and } \\
\text { trading labor, expertise, and equipment to } \\
\text { participate in subsistence activities. In the } \\
\text { salmon fisheries, cash income from commercial } \\
\text { harvest of salmon supports the financial } \\
\text { requirements of subsistence fishing; the } \\
\text { practices and social dynamics inherent in } \\
\text { fishing are learned and shared initially through } \\
\text { subsistence, and can also support commercial } \\
\text { fishing livelihoods. }\end{array}$ & $\begin{array}{l}\text { Sobelman 1985; Fall } \\
\text { et al. 1993; Buklis } \\
\text { 1999; Magdanz et al. } \\
\text { 2007; Reedy- } \\
\text { Maschner 2009; } \\
\text { Jenkins 2015; } \\
\text { BurnSilver et al. 2016) }\end{array}$ \\
\hline $\begin{array}{l}\text { User-group } \\
\text { conflicts }\end{array}$ & $\begin{array}{l}\text { Disagreement over allocation of salmon } \\
\text { harvests between subsistence, sport, personal } \\
\text { use, and commercial sectors; examples include } \\
\text { Upper Cook Inlet and the Copper River. }\end{array}$ & $\begin{array}{l}\text { Holen 2004; Fall and } \\
\text { Simeone 2010; } \\
\text { Dunker 2013; Loring } \\
\text { et al. } 2014\end{array}$ \\
\hline $\begin{array}{l}\text { Inter-region } \\
\text { conflicts }\end{array}$ & $\begin{array}{l}\text { Given the highly migratory nature of salmon, } \\
\text { the challenge of determining the stock of origin } \\
\text { of salmon during harvests creates conflicts } \\
\text { between fishermen that are dispersed along the } \\
\text { migratory pathway; examples include high-seas } \\
\text { interception, and Area M fisheries. }\end{array}$ & $\begin{array}{l}\text { Reedy-Maschner } \\
\text { 2010; Johnson and } \\
\text { Murphy } 2016\end{array}$ \\
\hline $\begin{array}{l}\text { Transboundary } \\
\text { issues }\end{array}$ & $\begin{array}{l}\text { Any management or conservation concern } \\
\text { relating to the ranges of salmon stocks that } \\
\text { encompass U.S. and Canadian waters; examples } \\
\text { include several mineral deposits that are slated } \\
\text { for exploration or development in British } \\
\text { Columbia in the headwaters of the Stikine, } \\
\text { Taku, and Alsek Rivers, and the Pacific Salmon } \\
\text { Treaty requiring minimum escapement of } \\
\text { salmon into Canadian waters of the Yukon } \\
\text { River. }\end{array}$ & $\begin{array}{l}\text { Burr 2015; Chadwick } \\
\text { et al. 2015; Conrad } \\
\text { and Gray } 2017\end{array}$ \\
\hline
\end{tabular}




\begin{tabular}{|c|c|c|}
\hline Abundance shifts & $\begin{array}{l}\text { Chinook salmon decline: several years of very } \\
\text { low Chinook salmon abundance, spread out } \\
\text { over three decades, have negatively impacted } \\
\text { all salmon user groups, particularly on the } \\
\text { Yukon and Kuskokwim rivers, but also on the } \\
\text { Kenai Peninsula and in Southeast Alaska; the } \\
\text { effects and their causes have become focal } \\
\text { points in conflicts between users and } \\
\text { management, and in how the resultant crises } \\
\text { have been handled over the short and long term } \\
\text { by state and federal fishery management } \\
\text { agencies. } \\
\text { Emerging Arctic subsistence salmon fisheries: } \\
\text { chum, pink, and chinook salmon harvests are } \\
\text { increasing in Arctic communities. }\end{array}$ & $\begin{array}{l}\text { Burr 2006; Carothers } \\
\text { et al. 2012; Dye and } \\
\text { Schwanke 2012; } \\
\text { Dunker 2013; Ikuta et } \\
\text { al. 2013; Loring and } \\
\text { Harrison 2013; Brown } \\
\text { et al. 2014; Burr 2015; } \\
\text { Brown et al. 2016; } \\
\text { Carothers et al. 2019 }\end{array}$ \\
\hline Sport use shifts & $\begin{array}{l}\text { More remote parts of the state are growing in } \\
\text { popularity among sport fishermen as road- } \\
\text { accessible streams in the Mat-Su Valley, the } \\
\text { Kenai Peninsula, and the Southeast become less } \\
\text { desirable due to crowding, habitat degradation, } \\
\text { and changing quality of experience; examples } \\
\text { include rivers in the Northwest Arctic near } \\
\text { Nome and Kotzebue, as well as tributaries of } \\
\text { the Kuskokwim and Yukon Rivers. }\end{array}$ & $\begin{array}{l}\text { Chadwick et al. 2015; } \\
\text { Dunaway } 1997\end{array}$ \\
\hline $\begin{array}{l}\text { Sport-dependent } \\
\text { regions }\end{array}$ & $\begin{array}{l}\text { Tourist destinations in Southeast and } \\
\text { Southcentral Alaska (e.g., Homer, Cooper } \\
\text { Landing, Sitka, Juneau), wherein commercial } \\
\text { charter fishing operations are significant } \\
\text { contributors to the local economy, have } \\
\text { increased in popularity over the past two } \\
\text { decades (with the exception of the } 2008 \\
\text { financial crisis and a handful of years after). }\end{array}$ & $\begin{array}{l}\text { Chadwick et al. } 2015 ; \\
\text { Paige et al. } 2009 ; \\
\text { Schwarz et al. } 2002\end{array}$ \\
\hline $\begin{array}{l}\text { Commercial- } \\
\text { dependent regions }\end{array}$ & $\begin{array}{l}\text { Several regions of the state are economically } \\
\text { and culturally dependent on commercial salmon } \\
\text { fisheries, including Bristol Bay, Kodiak, } \\
\text { Chignik, Alaska Peninsula/Aleutian Islands, } \\
\text { Southeast, and Cook Inlet. }\end{array}$ & $\begin{array}{l}\text { Apgar-Kurtz 2015; } \\
\text { Arnold 2009; Braund } \\
\text { 2017; Carothers 2015; } \\
\text { Himes-Cornell \& } \\
\text { Hoelting } 2015\end{array}$ \\
\hline Cultural roles & $\begin{array}{l}\text { The roles that salmon fill among different user } \\
\text { groups, geographies, ethnicities, and identities } \\
\text { are unique, but there are certainly } \\
\text { commonalities among them, including the } \\
\text { belief that salmon must be treated with respect } \\
\text { (however that may be defined). }\end{array}$ & $\begin{array}{l}\text { Brown et al. 2014; } \\
\text { Burr 2000; EPA 2014; } \\
\text { Langdon 2006a; } \\
\text { Napoleon 1991; } \\
\text { Raymond-Yakoubian } \\
\text { \& Raymond- } \\
\text { Yakoubian 2015 }\end{array}$ \\
\hline
\end{tabular}




\begin{tabular}{|c|c|c|}
\hline $\begin{array}{l}\text { Food \& livelihood } \\
\text { security }\end{array}$ & $\begin{array}{l}\text { Salmon, like all wild foods, play a significant } \\
\text { role in achieving food security in places with } \\
\text { historically high costs of living and expensive } \\
\text { store-bought foods. }\end{array}$ & $\begin{array}{l}\text { Braem et al. 2015; } \\
\text { Brown et al. 2012; } \\
\text { Brown et al. 2014; } \\
\text { Carothers et al. } 2012 \text {; } \\
\text { Sheldon et al. } 2016\end{array}$ \\
\hline $\begin{array}{l}\text { Subsistence \& } \\
\text { sharing }\end{array}$ & $\begin{array}{l}\text { This universal feature of subsistence describes } \\
\text { the dense, kin-based networks through which } \\
\text { wild resources flow within and across rural } \\
\text { communities; sharing and subsistence cannot be } \\
\text { separated. }\end{array}$ & $\begin{array}{l}\text { BurnSilver et al. 2016; } \\
\text { Carothers et al. 2019; } \\
\text { EPA 2014; Fall et al. } \\
\text { 1993; Ikuta et al. } \\
\text { 2016; Magdanz et al. } \\
\text { 2002, 2007; } \\
\text { Marchinoi et al. 2016; } \\
\text { Moncrieff 2007 }\end{array}$ \\
\hline $\begin{array}{l}\text { Salmon price } \\
\text { impacts }\end{array}$ & $\begin{array}{l}\text { Low ex-vessel prices for salmon, particularly } \\
\text { the period in the late 1990s/early 2000s brought } \\
\text { about by farmed salmon flooding global salmon } \\
\text { markets, had lasting impacts in many } \\
\text { commercially dependent regions and mixed } \\
\text { economies in the state; for state limited entry } \\
\text { permit holders, these impacts included sale of } \\
\text { rights in times of immediate cash needs and lost } \\
\text { ties between commercial fishing and the } \\
\text { community. }\end{array}$ & $\begin{array}{l}\text { Buklis 1999; Gho } \\
\text { 2014, 2015, 2016; } \\
\text { Himes-Cornell and } \\
\text { Hoelting 2015; Holen } \\
2017\end{array}$ \\
\hline $\begin{array}{l}\text { Local and } \\
\text { traditional } \\
\text { knowledge }\end{array}$ & $\begin{array}{l}\text { The practice of salmon fishing today, whether } \\
\text { for commercial, sport, personal use, or } \\
\text { subsistence purposes, is the product of local and } \\
\text { traditional salmon knowledge passed down and } \\
\text { revised through hundreds of generations; efforts } \\
\text { to incorporate multiple ways of knowing into } \\
\text { management of salmon systems has increased } \\
\text { in recent decades, but resistance still remains. }\end{array}$ & $\begin{array}{l}\text { Langdon 2006b; } \\
\text { Moncrieff 2007; } \\
\text { Moncrieff et al. 2009; } \\
\text { Carothers et al. 2019; } \\
\text { Carothers et al. 2014; } \\
\text { Naves et al. 2015; } \\
\text { Raymond-Yakoubian } \\
\text { and Raymond- } \\
\text { Yakoubian 2015; } \\
\text { Holen 2017; NOAA } \\
\text { Fisheries 2019 }\end{array}$ \\
\hline $\begin{array}{l}\text { Loss of access due } \\
\text { to privatization }\end{array}$ & $\begin{array}{l}\text { Inequitable distribution of fishing rights among } \\
\text { local and nonlocal resident groups, highly } \\
\text { overcapitalized fishing operations, and lost } \\
\text { access by communities local to the fishing } \\
\text { grounds across Alaska (although certain areas } \\
\text { have been more severely impacted than others) } \\
\text { have resulted from the shift to rights-based } \\
\text { fishery access. }\end{array}$ & $\begin{array}{l}\text { Carothers and } \\
\text { Chambers 2012; } \\
\text { Carothers 2015; } \\
\text { Himes-Cornell and } \\
\text { Hoelting 2015; } \\
\text { Donkersloot and } \\
\text { Carothers } 2016\end{array}$ \\
\hline
\end{tabular}




\begin{tabular}{|c|c|c|}
\hline $\begin{array}{l}\text { Industrial } \\
\text { development } \\
\text { concerns }\end{array}$ & $\begin{array}{l}\text { The friction between Alaska's renewable and } \\
\text { nonrenewable resource industries is evidenced } \\
\text { by recent examples of development projects } \\
\text { that have the potential to negatively impact } \\
\text { salmon habitat across the state, including the } \\
\text { Pebble Deposit in the headwaters of Bristol } \\
\text { Bay's major river systems, the Donlin mine in } \\
\text { the Kuskokwim region, the Ambler Mining } \\
\text { District in Northwest Alaska, and oil and gas } \\
\text { off the eastern Aleutian-Bering Sea coast. }\end{array}$ & $\begin{array}{l}\text { Reedy-Maschner and } \\
\text { Maschner 2012; EPA } \\
\text { 2014; Braem et al. } \\
\text { 2015; Braund } 2017\end{array}$ \\
\hline $\begin{array}{l}\text { Governance } \\
\text { conflicts }\end{array}$ & $\begin{array}{l}\text { At the core of state and federal governance } \\
\text { conflicts is how residents of rural communities } \\
\text { adjacent to subsistence resources are considered } \\
\text { by state and federal law; the State of Alaska } \\
\text { constitution does not allow for preferential } \\
\text { access to subsistence resources for one group of } \\
\text { Alaskans over another on state lands and } \\
\text { waters, while Title VIII of the Alaska National } \\
\text { Interest Lands Conservation Act (ANILCA) of } \\
1980 \text { expressly requires that preference to rural } \\
\text { subsistence users be given on federally } \\
\text { managed lands and waters. There differing } \\
\text { views of Tribal governance and co-management } \\
\text { of fisheries in Alaska, e.g., the rise of the } \\
\text { Intertribal Fish Commissions in Yukon and } \\
\text { Kuskokwim. }\end{array}$ & $\begin{array}{l}\text { Josephson 1997; } \\
\text { Holen 2004; Brown et } \\
\text { al. } 2012\end{array}$ \\
\hline $\begin{array}{l}\text { Consistency of } \\
\text { subsistence } \\
\text { harvests }\end{array}$ & $\begin{array}{l}\text { Several studies document the remarkable } \\
\text { consistency in subsistence harvest patterns at } \\
\text { the community level; the } 30-70 \text { or "super } \\
\text { households" rule in which } 30 \text { percent of the } \\
\text { households harvest } 70 \text { percent of the resources } \\
\text { that are used by all households in the } \\
\text { community, and the consistency of the total } \\
\text { amount (in edible pounds) of wild foods } \\
\text { gathered by community have remained stable } \\
\text { through time. }\end{array}$ & $\begin{array}{l}\text { Magdanz et al. 2002; } \\
\text { Brown et al. 2016; } \\
\text { BurnSilver et al. } 2016\end{array}$ \\
\hline
\end{tabular}




\begin{tabular}{|l|l|l|}
\hline Annual round & $\begin{array}{l}\text { The seasonal nature of salmon fishing and how } \\
\text { it fits into the annual, seasonal cycle of } \\
\text { subsistence harvests is key to contextualizing } \\
\text { ecological, economic, and social changes } \\
\text { related to subsistence; for example, shifting } \\
\text { salmon run timing and its effects on timing and } \\
\text { length of trips to fish camp in the summer are } \\
\text { features of human adaptation that would not be } \\
\text { evident without the necessary consideration of } \\
\text { annual patterns in subsistence activity. }\end{array}$ & $\begin{array}{l}\text { 2015 } \\
\text { Carothers 2012; Ikuta } \\
\text { al. 2013; Braem et }\end{array}$ \\
\end{tabular}

References Cited

Apgar-Kurtz, B. 2015. Factors affecting local permit ownership in Bristol Bay. Marine Policy, 56, 71-77. https://doi.org/10.1016/j.marpol.2015.02.013

Arnold, D. 2009. The fishermen's frontier: People and salmon in Southeast Alaska. Seattle: University of Washington Press.

Braem, N.M., E. Mikow, S.J. Wilson, \& M.L. Kostick. 2015. Wild Food Harvests in 3 Upper Kobuk River Communities: Ambler, Shugnak, and Kobuk, 2012-2013 (Technical Paper). Alaska Department of Fish and Game.

Braund, S. 2017. Set the net: The heritage and significance of fish camp and wild salmon in Bristol Bay, Alaska. Doctoral dissertation, University of Montana. [online] URL: http:// scholarworks.umt.edu/etd/11054/

Brown, C. L., N.M. Braem, M.L. Kostick, A.Trainor, L.J. Slayton, D.M. Runfola,... J.J. Simon. 2016. Harvests and Uses of Wild Resources in 4 Interior Alaska Communities and 3 Arctic Communities, 2014 (Technical Report No. 426). Alaska Department of Fish and Game.

Brown, C., L. Slayton, A. Trainor, D. Koster, \& M.L. Kostick. 2014. Wild Resource Harvests and Uses, Land Use Patterns, and Subsistence Economies in Manley Hot Springs and Minto, Alaska, 2012 (Technical Paper No. 400) (p. 278). Fairbanks, Alaska: Alaska Department of Fish and Game.

Buklis, L.S. 1999. A Description of Economic Changes in Commercial Salmon Fisheries in a Region of Mixed Subsistence and Market Economies. Arctic, 52(1), 40-48.

BurnSilver, S., M. Magdanz, R. Stotts, M. Berman, \& G. Kofinas. 2016. Are Mixed Economies Persistent or Transitional? Evidence Using Social Networks from Arctic Alaska: Are Mixed Economies Persistent or Transitional? American Anthropologist, 118(1), 121-129. https://doi.org/10.1111/aman.12447

Burr, J. 2015. Fishery Management Report for Sport Fisheries in the Yukon Management Area, 2013 (Fishery Management Report No. 15-30) (p. 66). Anchorage, Alaska: Alaska Department of Fish and Game.

Burr, J. 2006. Fishery Management Report for Sport Fisheries in the Arctic-Yukon Management Area, 2003-2005 (Fisheries Management Report No. 06-66) (p. 97). Anchorage, Alaska.

Burr, J. 2000. Fishery Management Report for Sport Fisheries in the Arctic-Yukon-Kuskokwim 
Management Area, 1998 (Fishery Management Report No. 00-12) (p. 94). Anchorage, Alaska: Alaska Department of Fish and Game.

Carothers, C. 2015. Fisheries privatization, social transitions, and well-being in Kodiak, Alaska. Marine Policy, 61, 313-322. https://doi.org/10.1016/j.marpol.2014.11.019

Carothers, C., T.L. Sformo, S. Cotton, J.C. George, \& P.A.H. Westley. 2019. Pacific salmon in the rapidly changing Arctic: Exploring local knowledge and emerging fisheries in Utqiagvik and Nuiqsut, Alaska. Arctic. 72(3).

Carothers, C., K.R. Criddle, C.P. Chambers, P.J. Cullenberg, J.A. Fall, A.H. Himes-Cornell, ... E.S. Springer (Eds.). 2012. Fishing People of the North: Cultures, Economies, and Management Responding to Change. Fairbanks, Alaska: Alaska Sea Grant, University of Alaska Fairbanks. [online] URL: http://seagrant.uaf.edu/bookstore/pubs/AKSG-12-03.html

Chadwick, B., B. Frenette, R. Chapell, P. Fowler, K. Piazza, \& B. Marston. 2015. Overview of the Sport Fisheries for King Salmon in Southeast Alaska through 2014: A Report to the Board of Fisheries (Special Publication No. 15-02) (p. 60). Anchorage, Alaska: Alaska Department of Fish and Game.

Conrad, S., and D. Gray. 2017. Overview of the 2016 Southeast Alaska and Yakutat Commercial, Personal Use, and Subsistence Salmon Fisheries. (Fishery Management Report No. 17-25). P. 30. Anchorage, Alaska. Alaska Department of Fish and Game.

Donkersloot, R. and C. Carothers. 2016. The graying of the Alaskan fishing fleet. Environment: Science and Policy for Sustainable Development. 58(3): 30-42. https://doi.org/ 10.1080/00139157.2016.1162011

Dunaway, D. 1997. Monitoring the Sport Fisheries of the Aniak River, Alaska, 1996 (Fisheries Management Report No. 97-4) (p. 64). Anchorage, Alaska: Alaska Department of Fish and Game.

Dunker, K. 2013. Upper Cook Inlet Personal Use Salmon Fisheries, 2010-2012 (Fisheries Data Series No. 13-59) (p. 65). Anchorage, Alaska: Alaska Department of Fish and Game.

Dye, J. E., and C. J. Schwanke. 2012. Report to the Alaska Board of Fisheries for the recreational fisheries of Bristol Bay, 2010-2012 (Special Publication No. 12-17) (p. 62). Alaska Department of Fish and Game.

EPA. 2014 Executive Summary of the Final Report, An Assessment of Potential Mining Impacts on Salmon Ecosystems of Bristol Bay, Alaska.

Fall, J. A., \& Simeone, W. E. 2010. Customary and Traditional Use Worksheet: Salmon, Chitina Subdistrict, Prince William Sound Management Area (Special Publication No. BOF 2010-04) (p. 164). Anchorage, Alaska: Alaska Department of Fish and Game.

Fall, J. A., D.B. Andersen, L. Brown, M. Coffing, G. Jennings, C. Mishler, ... V. Vanek. 1993. Noncommercial harvests and uses of wild resources in Sand Point, Alaska, 1992 (Technical Paper No. 226) (p. 167). Juneau, Alaska: Alaska Department of Fish and Game.

Gho, M. and C. Farrington. 2016. CFEC Report 16-3N, Changes in the Distribution of Alaska's Commercial Fisheries Entry Permits, 1975 - 2015.

Gho, M. 2016. CFEC Permit Holdings and Estimates of Gross Earnings in the Kodiak Commercial Salmon Fisheries, 1975-2015. Alaska Department of Fish and Game.

Gho, M. 2015. CFEC Permit Holdings and Estimates of Gross Earnings in the Bristol Bay 
Commercial Salmon Fisheries, 1975-2014. Alaska Department of Fish and Game.

Gho, M. 2014. CFEC Permit Holdings and Estimates of Gross Earnings in the Prince William Sound Salmon Fisheries, 1975-2013. Alaska Department of Fish and Game.

Himes-Cornell, A., and K. Hoelting. 2015. Resilience strategies in the face of short- and longterm change: Out-migration and fisheries regulation in Alaskan fishing communities. Ecology and Society, 20(2). https://doi.org/10.5751/ES-07074-200209

Holen, D. 2017. Subsistence and Commercial Fisheries Through the Lenses of Culture and Economy in Three Coastal Alaskan Communities (Dissertation). University of Alaska Fairbanks, Fairbanks, AK.

Holen, D. L. 2004. The Atna' and the political ecology of the Copper River fishery, Alaska. Arctic Anthropology 4(1):58-70.

Ikuta, H., A.R. Brenner, \& A. Godduhn. 2013. Socioeconomic patterns in subsistence salmon fisheries: historical and contemporary trends in five Kuskokwim River communities and overview of the 2012 season (Technical Paper No. 382) (p. 171). Fairbanks, Alaska: Alaska Department of Fish and Game.

Jenkins, D. 2015. Impacts of neoliberal policies on non-market fishing economies on the Yukon River, Alaska. Marine Policy, 61, 356-365. https://doi.org/10.1016/j.marpol.2014.12.004

Johnson, R.H. and R.L. Murphy. 2016. North Alaska commercial salmon annual management report, 2015. Alaska Department of Fish and Game, Fishery Management Report No. 16-03, Anchorage.

Josephson, A. 1997. Katie John and Totemoff: The United States and Alaska Clash over the Reserved Water Rights Doctrine and Native Alaska Hunting and Fishing Rights-The US Supreme Court Passes on an Opportunity to Resolve the Subsistence Debate. Dickson Journal of Environmental Law and Policy, 6, 225.

Langdon, S. 2006a. Tidal Pulse Fishing: Selective Traditional Tlingit Salmon Fishing Techniques on the West coast of the Prince of Wales Archipelago. In ed. C. Menzies. Traditional Ecological Knowledge and Natural Resource Management. 21-46. Lincoln, NE.: University of Nebraska Press.

Langdon, S. 2006b. Traditional Knowledge and Harvesting of Salmon by HUNA and HINYAA LINGIT. Fisheries Information Service Report 02-104. Anchorage: US Department of Interior, Fish and Wildlife Service, Office of Subsistence Management.

Loring, P., H. Harrison, \& S. Gerlach. 2014. Local Perceptions of the Sustainability of Alaska's Highly Contested Cook Inlet Salmon Fisheries. Society \& Natural Resources, 27(2), 185199.

Loring, P., and H. Harrison. 2013. "That's what opening day is for:” social and cultural dimensions of (not) fishing for salmon in Cook Inlet, Alaska. Maritime Studies, 12(1), 12. [online] URL: https://maritimestudiesjournal.springeropen.com/articles/ 10.1186/2212-9790-12-12

Marchioni, M., J. Fall, J. B. Davis, \& G. Zimpleman. 2016. Kodiak City, Larsen Bay and Old Harbor: An Ethnographic Study of Traditional Subsistence Salmon Harvests and Uses (Technical Paper No. 418) (p. 205). Anchorage, Alaska: Alaska Department of Fish and Game.

Magdanz, J., S. Tahbone, A. Ahmasuk, D. Koster, D., \& B. Davis. 2007. Customary Trade and Barter in Fish in the Seward Peninsula Area, Alaska (Technical Paper No. 328). Juneau, 
Alaska: Alaska Department of Fish and Game.

Magdanz, J., C.J. Utermohle, \& R.J. Wolfe. 2002. The Production and Distribution of Wild Food in Wales and Deering, Alaska (Technical Report No. 259). Juneau, Alaska: Alaska Department of Fish and Game.

Moerlein, K., and C. Carothers. (2012). Total Environment of Change: Impacts of Climate Change and Social Transitions on Subsistence Fisheries in Northwest Alaska. Ecology and Society, 17(1). https://doi.org/10.5751/ES-04543-170110

Moncrieff, C. 2007. Traditional ecological knowledge of customary trade of subsistenceharvested fish on the Yukon River. US Fish and Wildlife Service, Office of Subsistence Management, Fisheries Resource Monitoring Program, 2007 Final Report (Study No. 04-265). Yukon River Drainage Fisheries Association, Anchorage, Alaska. [online] URL: http://www.arlis.org/docs/vol1/H/169946050.pdf

Moncrieff, C., C. Brown, \& L. Sill. 2009. 2009 Arctic Yukon Kuskokwim Sustainable Salmon Initiative Project Final Product: Natural Indicators of Salmon Run Abundance and Timing, Yukon River. [online] URL: http://www.aykssi.org/wp-content/uploads/622Moncrieff-FR.pdf

Napoleon, H. 1991. Yuuyaraq: The way of the human being. Eric Madsen, Editor. Fairbanks, Alaska: Center for Cross-Cultural Studies, University of Alaska Fairbanks.

Paige, A. W., S. Churchill, N. Ratner, M. Turek, \& P. Coiley-Kenner. 2009. Local Knowledge, Harvest Patterns, and Community Uses of Salmon in Wrangell, Alaska (Technical Paper No. 323) (p. 105). Juneau, Alaska: Alaska Department of Fish and Game.

Raymond-Yakoubian, B., and J. Raymond-Yakoubian. 2015. "Always taught not to waste": Traditional Knowledge and Norton Sound/Bering Strait Salmon Populations. [online] URL: http://www.kawerak.org/forms/nr/TK\%20of\%20Salmon $\% 20$ Final\%20Report.pdf

Reedy-Maschner, K. 2009. Entangled Livelihoods: Economic Integration and Diversity in the Western Arctic. Alaska Journal of Anthropology, 7(2), 135-146. [online] URL: https:// www.alaskaanthropology.org/wp-content/uploads/2015/11/AJA-v72optimized.pdf\#page $=139$

Reedy-Maschner, K. 2010. Aleut Identities: Tradition and Modernity in an Indigenous Fishery. Montreal: McGill - Queen's University Press.

Reedy-Maschner, K., and H. Maschner. 2012. A Subsistence Study for the North Aleutian Basin (OCS Study BOEM No. 2012-109) (p. 428). Anchorage, Alaska: Bureau of Ocean Energy Management.

Schwarz, L., D.A. Tracy, \& S. Schmidt. 2002. Area Management Report for the Recreational Fisheries of the Kodiak and Alaska Peninsula/Aleutian Islands Regulatory Areas, 1999 and 2000 (Fishery Management Report No. 02-02) (p. 224). Anchorage, Alaska: Alaska.

Shelden, C. A., T. Hamazaki, M. Horne-Brine, I. Dull, \& R. Frye. 2016. Subsistence salmon harvests in the Kuskokwim area, 2014 (Fishery Data Series No. 16-49) (p. 82). Anchorage, Alaska: Alaska Department of Fish and Game.

Simeone, W. and J. Kari. 2002. Traditional Knowledge and Fishing Practices of the Ahtna of the Copper River, Alaska. Technical Paper No. 270. Alaska Department of Fish and Game, Division of Subsistence. Juneau, AK.

Sobelman, S. S. 1985. The Economics of Wild Resource Use in Shishmaref, Alaska. (Technical Report No. 112). Fairbanks, Alaska: Alaska Department of Fish and Game. 
Veltre, D.W., and M.J. Veltre. 1983. Resource utilization in Atka, Aleutian Islands, Alaska (Technical Paper No. 88) (p. 230). Alaska Department of Fish and Game. 